\title{
Effect of physical and chemical parameters on the $\beta$-Tricalcium phosphate synthesized by the wet chemical method
}

\author{
Asmaa Massit ${ }^{1}$, Majda Fathi ${ }^{1}$, Ahmed El Yacoubi ${ }^{1}$, Abdelilah Kholtei ${ }^{2}$ and \\ Brahim Chafik El Idrissi ${ }^{1, *}$ \\ ${ }^{1}$ Chemical Team Materials Surfaces Interfaces, Laboratory Materials and Energetics, \\ Faculty of Sciences, University Ibn Tofail, kenitra, Po Box 133, Kénitra, Morocco \\ ${ }^{2}$ Laboratory Chemistry_Biology Applied to Environment, Faculty of Sciences, University Moulay Ismail, \\ Po Box 11201, Zitoun Meknes, Morroco
}

\begin{abstract}
In this paper, the synthesis of nanosized powders $\beta$-Tricalcium phosphate $\beta-\mathrm{Ca}_{3}\left(\mathrm{PO}_{4}\right)_{2}$ was studied by the wet chemical method at different values of reaction temperature, initial concentration of diammonium hydrogen phosphate $\left(\mathrm{NH}_{4}\right)_{2} \mathrm{HPO}_{4}$, calcium nitrate tetrahydrate $\mathrm{Ca}\left(\mathrm{NO}_{3}\right)_{2} \cdot 4 \mathrm{H}_{2} \mathrm{O}$ addition rate, $\mathrm{pH}$ of reaction and aging time. All these parameters have a great impact on the properties of the resulting $\beta$-TCP nano powders. Analysis results of morphology, structure of TCP powder from infrared (IR) spectra, X-ray diffraction (XRD) and transmission electron microscopy (TEM) indicated that the synthesized TCP powder had spherical crystal shape with crystallite size, calculated by XRD method, less than $60 \mathrm{~nm}$, mono and biphasic structure composed of $\beta$ TCP with pyrophosphate calcium or hydroxyapatite. The variation of the synthesis conditions did not affect the morphology, but it affect the size of crystallites and particles.
\end{abstract}

Keywords: $\beta$-tricalcium phosphate; Wet chemical method; Synthesis conditions; crystallite size.

\section{Introduction}

Tricalcium phosphate (TCP) is one of the variations of the calcium phosphate compounds with more applications in bone tissue regeneration ${ }^{1-3}$, due to its chemical composition $\mathrm{Ca}_{3}\left(\mathrm{PO}_{4}\right)_{2}$ being similar to the natural bone tissue ${ }^{4}$. TCP is widely used in the biomedical field because of excellent biocompatibility, high bioactivity, non-toxicity and non-inflammatory behaviour and non-immunogenic properties. It can exist in two possible forms, $\alpha$ and $\beta$, and normally $\beta$ form gets converted into $\alpha$ with annealing at temperatures higher than $1250-1300^{\circ} \mathrm{C}^{5}$. The $\beta$-TCP is bioresorbable, and bioresorption occurs through osteoclastic activity ${ }^{6,7}$. It has good biodegradability and higher dissolution rate in the body's environment after implantation, which is absorbed and replaced by new bone ${ }^{8}$. Many methods are used to synthesize of such biomaterials including wet-chemical method ${ }^{9,10}$, solid-state process ${ }^{11,12}$ and microwave irradiation ${ }^{13,14}$, sol-gel, etc ${ }^{15,16}$. The most conventional is the precipitation in aqueous medium starting from $\mathrm{Ca}\left(\mathrm{NO}_{3}\right)_{2}$ and $\left(\mathrm{NH}_{4}\right)_{2} \mathrm{HPO}_{4}$ as raw materials. It is noteworthy that $\beta$-TCP cannot be precipitated from solution, but only be prepared by calcination, e.g. of Apatitic tricalcium phosphate $\mathrm{Ca}_{9}\left(\mathrm{HPO}_{4}\right)\left(\mathrm{PO}_{4}\right)_{5}(\mathrm{OH})$ at temperatures over $750^{\circ} \mathrm{C}^{17}$.

$$
\begin{gathered}
9 \mathrm{Ca}\left(\mathrm{NO}_{3}\right)_{2}+6\left(\mathrm{NH}_{4}\right)_{2} \mathrm{HPO}_{4}+6 \mathrm{NH}_{4} \mathrm{OH} \rightarrow \mathrm{Ca} 9\left(\mathrm{HPO}_{4}\right)\left(\mathrm{PO}_{4}\right)_{5} \mathrm{OH}+18 \mathrm{NH}_{4} \mathrm{NO}_{3}+5 \mathrm{H}_{2} \mathrm{O} \\
\mathrm{Ca}_{9}\left(\mathrm{HPO}_{4}\right)\left(\mathrm{PO}_{4}\right)_{5} \mathrm{OH} \rightarrow 3 \mathrm{Ca}_{3}\left(\mathrm{PO}_{4}\right)_{2}+\mathrm{H}_{2} \mathrm{O}
\end{gathered}
$$

However, the synthesis of a pure $\beta$-TCP by this method requires close control of many parameters such as reaction $\mathrm{pH}$, temperature, the stoichiometry of the raw materials, ageing time. A slight variation of these experimental parameters can generate drastic variations in the composition of the final product ${ }^{18}$

*Corresponding author: Brahim Chafik El Idrissi

Email address: chidrissi@yahoo.fr DOI: http://dx.doi.org/10.13171/mjc7310268-elidrissi and reveal the pyrophosphate calcium phase $\left(\mathrm{Ca}_{2} \mathrm{P}_{2} \mathrm{O}_{7}\right.$ or $\mathrm{CPP})$ or the hydroxyapatite phase $\left(\mathrm{Ca}_{10}\left(\mathrm{PO}_{4}\right)_{6}(\mathrm{OH})_{2}\right.$ or HAp). These conditions remain specific and should be controlled by synthesis preparation parameters ${ }^{13,19}$. Therefore, it is crucial for biomedical applications to control some parameters of

Received August 12, 2018

Accepted October 10, 2018

Published October 26, 2018 
TCP particles such as crystallite size, morphology and phase composition. Bioactivity of calcium phosphate materials depends on many factors during the synthesis procedure including precursor reagents, impurity contents, crystal size and morphology, concentration and mixture order of reagents, $\mathrm{pH}$ and temperature. Such conditions are application specific and should be controlled by synthesis preparation parameters ${ }^{13,19}$. Therefore, controlling crystallite size, morphology and phase composition of TCP is very important for biomedical applications.

In this paper, we present some results of $\beta$-TCP nanopowder synthesized by the wet chemical method and the effects of synthetic conditions, i.e. reaction temperature, ageing time, $\mathrm{pH}$ of mixture solution, $\left(\mathrm{NH}_{4}\right)_{2} \mathrm{HPO}_{4}$ addition rate and reactant concentration on crystallite size, fraction of crystallinity and morphology.

\section{Materials and Methods}

Tricalcium phosphate was synthesized by the wet chemical method using $\left(\mathrm{NH}_{4}\right)_{2} \mathrm{HPO}_{4}$ solution at the various $\left(\mathrm{NH}_{4}\right)_{2} \mathrm{HPO}_{4}$ (Riedel-de Haën, Germany) concentrations $0.15,0.20,0.25 \mathrm{M}$ in distilled water. The $\mathrm{Ca}\left(\mathrm{NO}_{3}\right)_{2} \cdot 4 \mathrm{H}_{2} \mathrm{O}$ (Scharlau, Spain) concentration was set at $0.36 \mathrm{M}$ to obtain the $\mathrm{Ca} / \mathrm{P}$ molar ratio of 1.50. Its solution was added dropwise into $\left(\mathrm{NH}_{4}\right)_{2} \mathrm{HPO}_{4}$ solution with addition rate of 3, 30 and $300 \mathrm{ml} \mathrm{min}^{-1}$ under a constant stirring condition. During the synthesizing process, the $\mathrm{pH}$ value varies between 7 and 9 . The $\mathrm{pH}$ of the solution was adjusted by the addition of ammonium hydroxide $\mathrm{NH}_{4} \mathrm{OH}$. The reaction was conducted at different temperatures (30, $40,50,60$ and $70^{\circ} \mathrm{C}$ ). This precipitated solution was stirred for $2 \mathrm{~h}$ and aged at room temperature (RT) for different times $(2,24,48$ and $72 \mathrm{~h})$. The precipitate was filtered and washed repeatedly using distilled water to remove $\mathrm{NH}_{4}{ }^{+}$and $\mathrm{NO}_{3}{ }^{-}$ions. The resultant precipitate was dried at $70^{\circ} \mathrm{C}$ for $24 \mathrm{~h}$ in a dry oven and then crushed in a mortar. The powders were calcined at $800^{\circ} \mathrm{C}$ for $1 \mathrm{~h}$.

The phase purity and crystallinity of the TCP powder were analyzed by X-ray diffraction (XRD) (XPERT-PROPW3050/60 ( $\theta / \theta)$ using $\mathrm{CuK} \alpha$ radiation $\lambda=1.54056 \AA$ and operating at $45 \mathrm{kV}$ and $40 \mathrm{~mA}$, step angle of $0.03^{\circ}$ and $2 \theta$ in range of $15-60^{\circ}$. Crystalline phases detected in the patterns were identified by comparison to the standard patterns from the ICDDPDF (International Center for Diffraction DataPowder Diffraction Files). The crystallite dimensions (D) were calculated using Debye-Scherrer Eq. (1):

$\mathrm{D}=0.9 \lambda / \mathrm{FWHM} \cdot \cos \theta$

Where $\mathrm{D}$ is the crystallite size $(\mathrm{nm}), \lambda$ the wavelength of X-ray beam $(0.15406 \mathrm{~nm}$ for $\mathrm{Cu}-\mathrm{K} \alpha$ radiation), FWHM the full width at half maximum for the diffraction peak under consideration ( $\mathrm{rad})$, and $\theta$ is the diffraction angle $\left(^{\circ}\right)$. The crystallinity noted by $\mathrm{Xc}$ corresponds to the fraction of crystalline $\beta$-TCP phase in the investigated volume of powdered sample, evaluated by the Eq (2):

$\mathrm{Xc}=1-\mathrm{V}_{300 / 0210} / \mathrm{I}_{0210}$

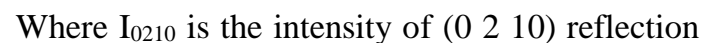
of $\beta$-TCP structure and $\mathrm{V}_{300} / 0210$ is the intensity of the hollow between $\left(\begin{array}{lll}3 & 0 & 0\end{array}\right)$ and $\left(\begin{array}{lll}0 & 2 & 10\end{array}\right)$ reflections ${ }^{20,21}$.

The characteristic functional groups of $\beta$-TCP were identified by Fourier transform infrared (FTIR) spectroscopy, VERTEX 70, Genesis Series (400-4000 cm-1, resolution 4, scans 20). For this $1 \%$ of the powder was mixed and ground with $99 \% \mathrm{KBr}$ and the spectrum was taken in the range of 400 to $4000 \mathrm{~cm}^{-1}$.

The size and morphology of fine TCP powder were observed on a transmission electron microscope (Philips CM10, Eindhoven, The Netherlands) that operated at the acceleration voltage of $100 \mathrm{kV}$.

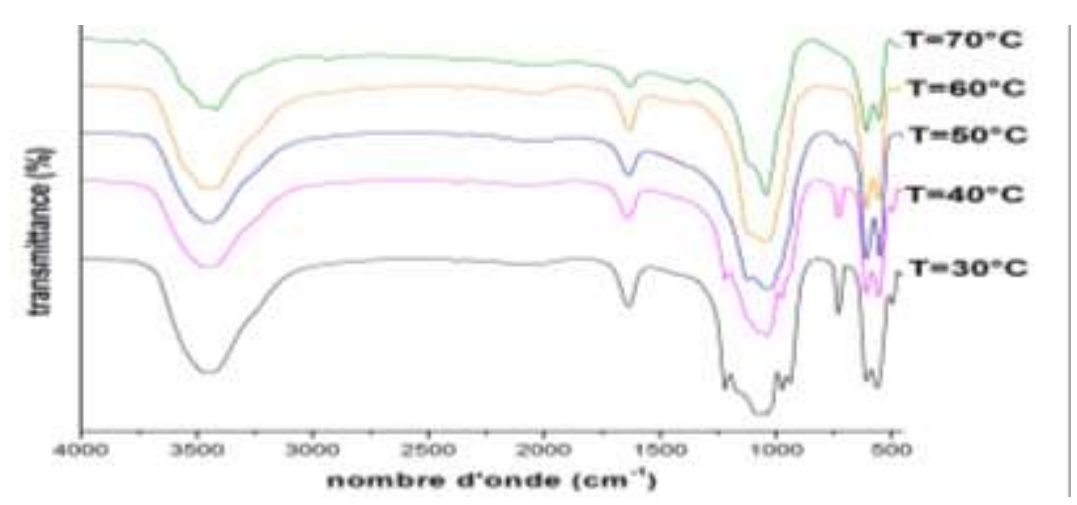

Figure 1. IR spectra of TCP powder synthesized at different temperatures.

\section{Results and Discussion}

The reaction temperature was an important factor that could affect the morphology, the phase structure and the crystallinity of the synthesized TCP powder. (Fig. 1) and Table 1 show the FTIR spectra and the bonds of the functional groups of the TCP powder synthesized using $\mathrm{Ca}\left(\mathrm{NO}_{3}\right)_{2} .4 \mathrm{H}_{2} \mathrm{O}$ and $\left(\mathrm{NH}_{4}\right)_{2} \mathrm{HPO}_{4}$ 
solution at the different reaction temperatures, with $\left(\mathrm{NH}_{4}\right)_{2} \mathrm{HPO}_{4}$ concentration of $0.15 \mathrm{M}$ and at an addition rate of about $300 \mathrm{ml} / \mathrm{min}$, at an aging time of $2 \mathrm{~h}$ and at a pH of about 9. The IR spectra of all synthesized samples showed the characteristic peaks corresponding to $\beta$-TCP ${ }^{22}$. The bands at 1043 and $1078 \mathrm{~cm}^{-1}$ corresponded to the triple degenerate $v 3$ antisymmetric stretching vibration of $\mathrm{PO}_{4}{ }^{3-} .968 \mathrm{~cm}^{-1}$ band was assigned to $v 1$, the symmetric stretching vibration of $\mathrm{PO}_{4}^{3-}$. The bands at 607 and $559 \mathrm{~cm}^{-1}$ corresponded to the triple degenerate $v 4$ antisymmetric stretching mode. The peak and the broad band of the single molecule of adsorbed water were also discerned at 1633 and between 3700 and $3100 \mathrm{~cm}^{-1}$ respectively. Moreover, the FTIR had shown the presence, at 729 and $1218 \mathrm{~cm}^{-1}$, of $\mathrm{P}_{2} \mathrm{O}_{7}^{4-}$ group, which is characteristic to the calcium pyrophosphate phase $\beta-\mathrm{Ca}_{2} \mathrm{P}_{2} \mathrm{O}_{7}$ (JCPDF 9-346). With the temperature rising, these bands become narrower and low then gradually disappear.

Table 1. Wave numbers for the functional groups of TCP.

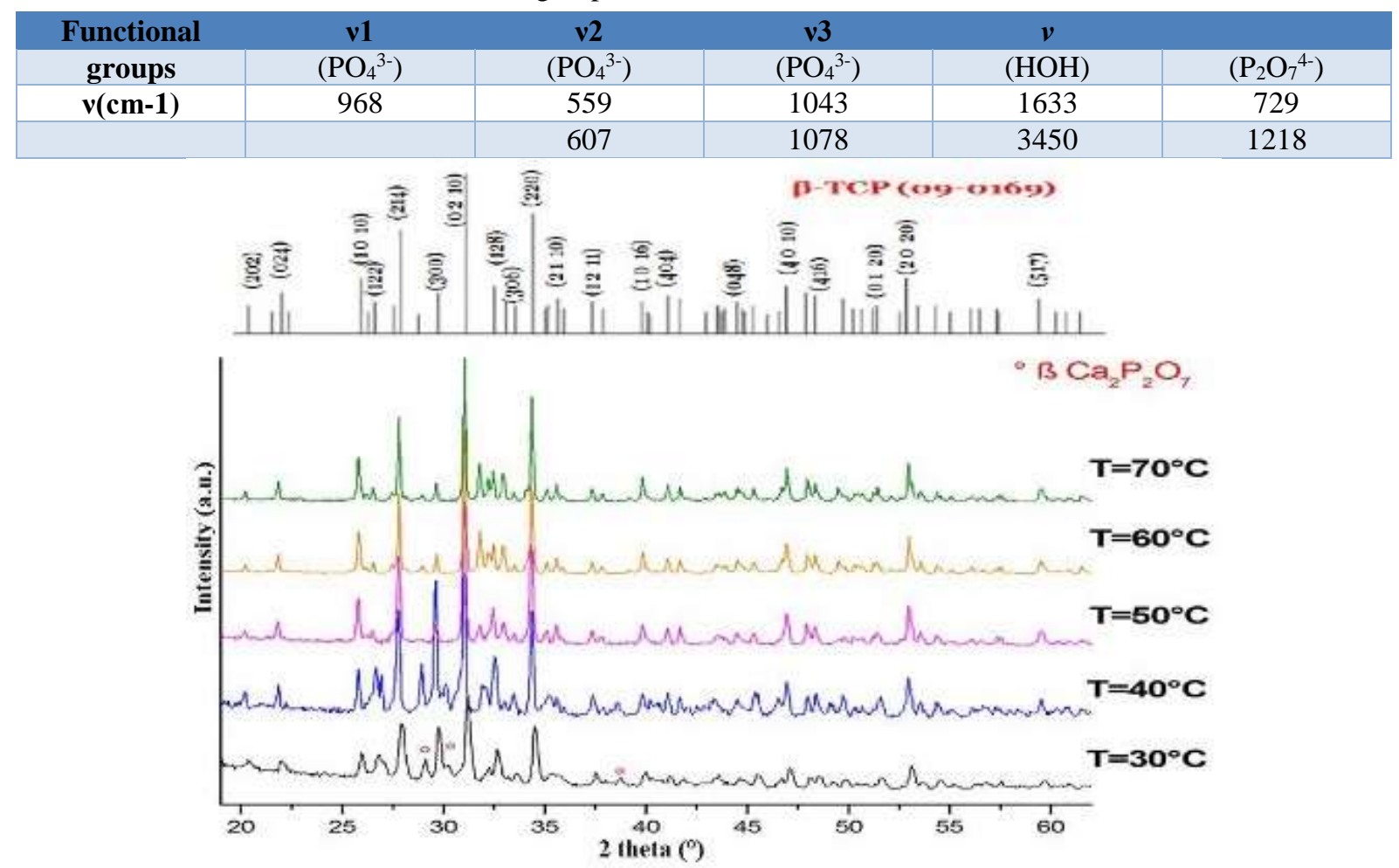

Figure 2. XRD spectra of TCP powder synthesized at different temperatures.

The XRD spectra of the TCP powder synthesized at the various temperatures are shown in (Fig. 2). All XRD patterns show diffraction peaks characteristics of $\beta$-Tricalcium phosphate presents in standards and in literature. The major phase, as expected, is $\beta$-TCP, which is confirmed by comparing data obtained with the ICDD PDF 009-0169. Powders exhibited sharp diffraction peaks indicating high crystallinity. Conversely, in the $\beta$-TCP powders prepared at reaction temperatures 30 and $40^{\circ} \mathrm{C}$, and in agreement with the previous FTIR results, besides the $\beta$-TCP, an additional peak is detected at $2 \theta=28.9^{\circ}$ such peak corresponds to $\beta$-CPP phase.

Table 2. The crystal diameter and crystallinity of TCP powder synthesized at different temperatures.

\begin{tabular}{|c|c|c|}
\hline Temperature & Crystal Diameter & Xrystallinity $_{\mathrm{C}}$ \\
\hline$\left.{ }^{\circ} \mathbf{C}\right)$ & $(\mathrm{nm})$ & 93 \\
\hline $\mathbf{3 0}$ & 20 & 97 \\
\hline $\mathbf{4 0}$ & 37 & 99 \\
\hline $\mathbf{5 0}$ & 41 & 99 \\
\hline $\mathbf{6 0}$ & 55 & 99 \\
\hline
\end{tabular}

The TCP crystal diameter calculated from the Scherrer equation showed that the crystal diameter and degree of crystallinity increased from 20 to $59 \mathrm{~nm}$ and from 93 to 99 on increasing the reaction temperature from 30 to $70^{\circ} \mathrm{C}$, respectively Table 2 .
Increasing the temperature results in faster motion of molecules, so there was an increased chance of therm colliding with each other; the TCP particles concentrated to form larger particles. At $30^{\circ} \mathrm{C}$, the TCP particle had the smallest diameter. It has been 
found that the control of the crystallinity of calcium phosphates is necessary for their biological applications ${ }^{23}$. Since calcium phosphates with lowlevel of crystallinity show high osteoconductivity, the synthesized powders can be used to promote osseointegration or used as a coating to promote bone in growth into prosthetic implants ${ }^{24}$.

\section{Effect of reactant concentration}

By varying the precursor concentration, the kinetics of TCP precursor synthesis can be affected. By increasing the precursor concentration, the solubility limit at a given $\mathrm{pH}$ is more rapidly exceeded, creating a burst of primary nuclei for crystal growth. However, as the reactants are continually added, the primary nuclei continue to grow rapidly high precursor concentrations resulted in larger crystallite and particle sizes. (Fig. 3) presents the IR spectra of the TCP powder obtained at various initial concentrations of $\left(\mathrm{NH}_{4}\right)_{2} \mathrm{HPO}_{4}$ solution at room temperature, at an addition rate of about $300 \mathrm{ml} / \mathrm{min}$, at an ageing time of $48 \mathrm{~h}$ and at a pH of about 9 . It could be found that the IR spectra of the TCP samples had the same shapes and the characteristic peaks of the functional groups of TCP are shown. The very weak band of the secondary phase, $\mathrm{P}_{2} \mathrm{O}_{7}$ at $728 \mathrm{~cm}^{-1}$, gradually disappeared during the decrease in the concentration of $\left(\mathrm{NH}_{4}\right)_{2} \mathrm{HPO}_{4}$ solution from 0.25 to 0.15 .

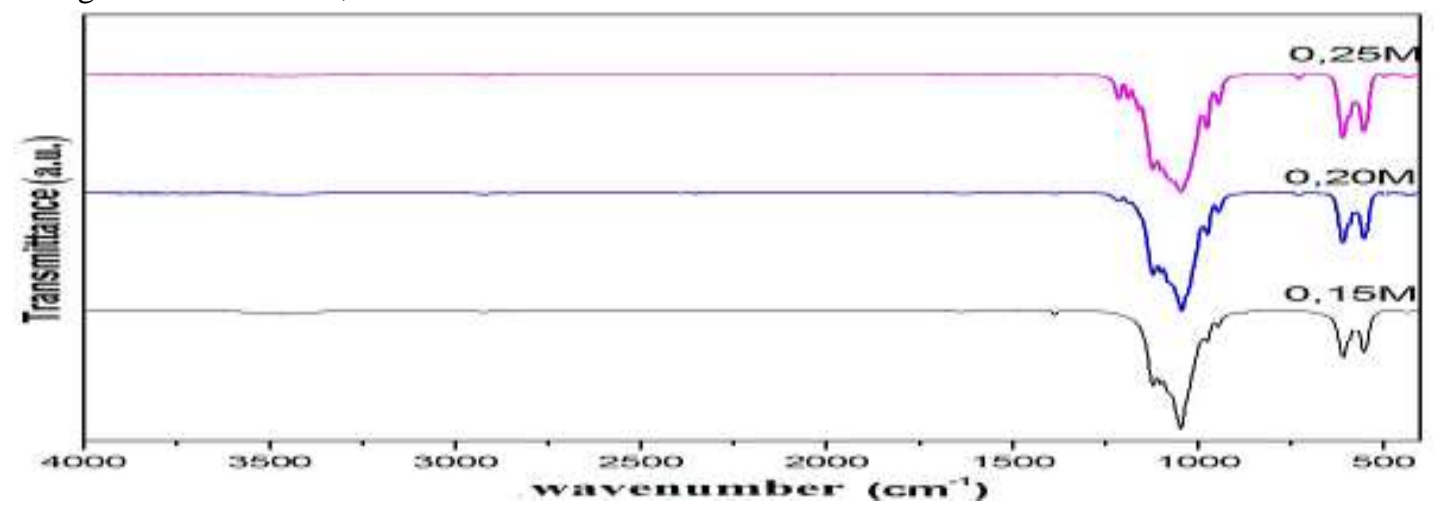

Figure 3. IR spectra of the TCP samples synthesized at different initial concentrations of $\left(\mathrm{NH}_{4}\right)_{2} \mathrm{HPO}_{4}$ solution

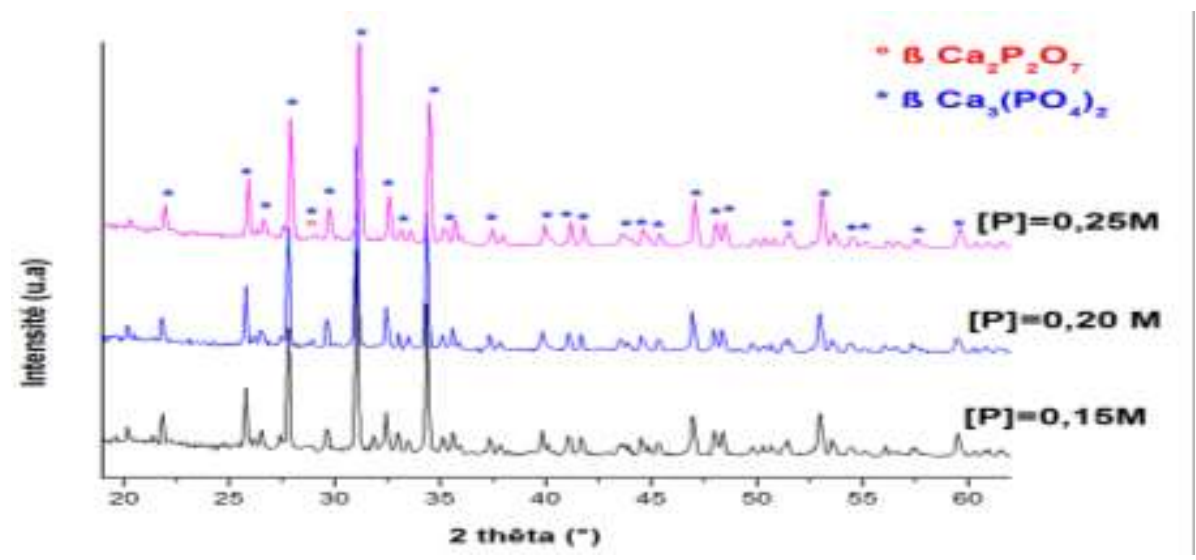

Figure 4. IR spectra of the TCP samples synthesized at different initial concentrations of $\left(\mathrm{NH}_{4}\right)_{2} \mathrm{HPO}_{4}$ solution

(Fig. 4) and Table 3 introduce XRD spectra and XRDcalculated crystal diameters and crystallinity, respectively. In general, XRD patterns of the TCP samples had the same shapes and had only the characteristics peaks of the TCP molecule. The insignificant amount of $\mathrm{Ca}_{2} \mathrm{P}_{2} \mathrm{O}_{7}$ detected by FTIR in the samples synthesized with 0.25 and $0.2 \mathrm{M}$ is undetectable by XRD. For powder prepared at 0.15 $\mathrm{M}$, besides the $\beta$-TCP, an additional small peak is detected at $2 \theta=31.8^{\circ}$ such peak corresponds to Hap (JCPDS 9-0432) phase. The crystal diameter was in a range from 40 to $51 \mathrm{~nm}$. XRD analysis also shows a weak effect of reacting concentration (in the abovementioned range) on the TCP crystal diameter.

Table 3. The crystal diameter and crystallinity of TCP powder synthesized at various $\left(\mathrm{NH}_{4}\right)_{2} \mathrm{HPO}_{4}$ concentrations.

\begin{tabular}{|c|c|c|}
\hline Concentration of & Crystal Diameter & \multicolumn{2}{|c|}{ Crystallinity } \\
\hline $\mathbf{N H}_{\mathbf{4}} \mathbf{H}_{\mathbf{H}} \mathbf{H O}_{\mathbf{4}} \mathbf{( M )}$ & $(\mathrm{nm})$ & $\mathrm{X}_{\mathrm{C}}$ \\
\hline $\mathbf{0 . 1 5}$ & 48 & 99 \\
\hline $\mathbf{0 . 2 0}$ & 51 & 99 \\
\hline $\mathbf{0 . 2 5}$ & 40 & 99 \\
\hline
\end{tabular}




\section{Effect of $\mathrm{Ca}\left(\mathrm{NO}_{3}\right)_{2}$ addition rate}

The adding rate of $\mathrm{Ca}\left(\mathrm{NO}_{3}\right)_{2}$ affects the morphology, structure and size of formed TCP crystals. By varying the precursor addition rate, nucleation and crystal growth rates can be controlled. Rapid addition of precursors results in localized high concentrations of precursors, exceeding the solubility of TCP in those regions, which favors nucleation and formation of small crystals ${ }^{25}$. (Fig. 4) presents the IR spectra of the samples synthesized with the dropping rates of 3, 30 and $300 \mathrm{ml} \cdot \mathrm{min}^{-1}$ at RT, at an ageing time of $48 \mathrm{~h}$ and at a $\mathrm{pH}$ of about 9 . All IR spectra of the samples have similar shapes and the specific peaks corresponding to functional groups in the $\beta$-TCP molecule. The bands at 725 and $1200 \mathrm{~cm}^{-1}$ indicated the presence of $\mathrm{P}_{2} \mathrm{O}_{7}^{4-}$ groups.

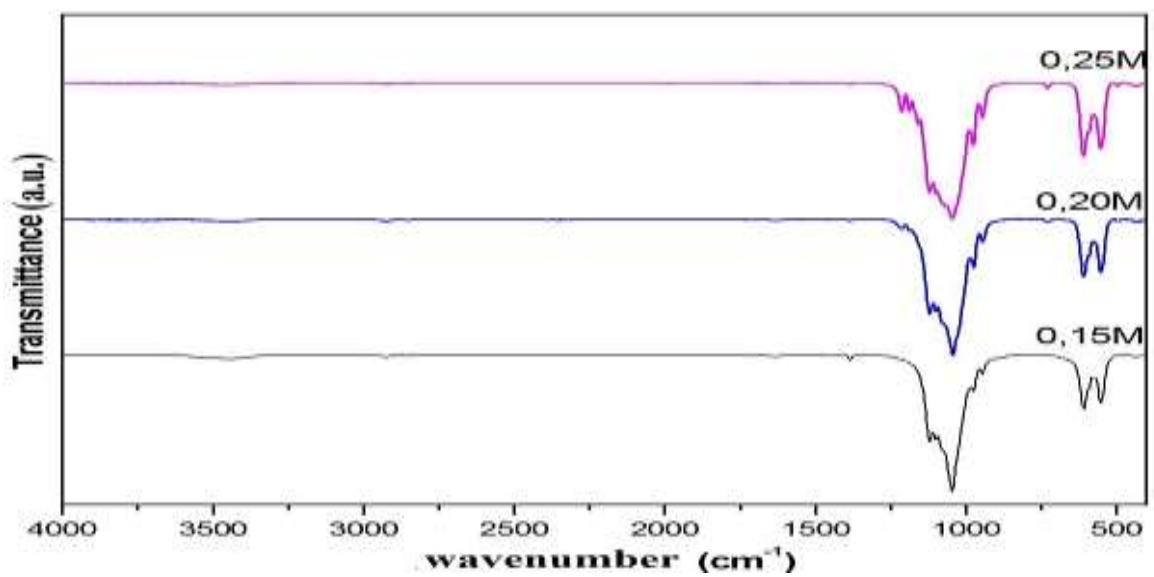

Figure 5. IR spectra of TCP powder synthesized at different $\mathrm{Ca}\left(\mathrm{NO}_{3}\right)_{2}$ addition's rates

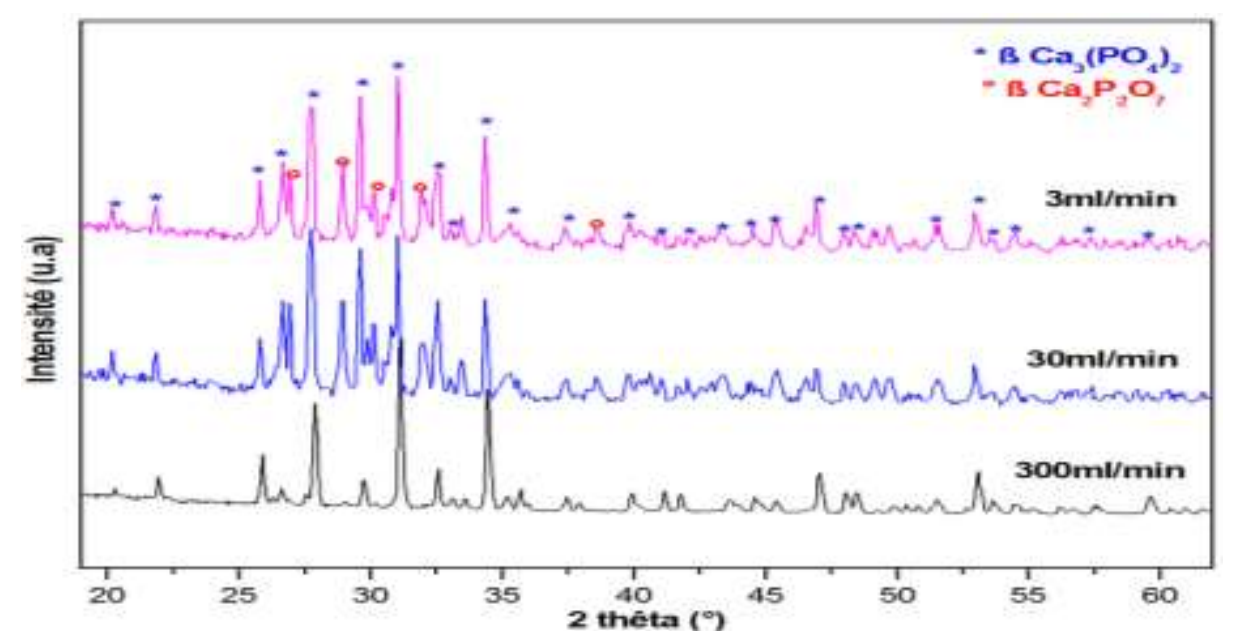

Figure 6. X-ray spectra of TCP powder synthesized at different $\mathrm{Ca}\left(\mathrm{NO}_{3}\right)_{2}$ addition's rates

(Fig. 6) and Table 4 introduce XRD spectra and XRD-calculated crystal diameters and crystallinity, respectively. XRD patterns of the $\beta$-TCP samples had the same shapes and had all the characteristics peaks of the molecule. The diffractograms of the samples prepared with a precursor addition rate of $30 \mathrm{ml} / \mathrm{min}$ and $3 \mathrm{ml} / \mathrm{min}$ show additional peaks relative to the group $\mathrm{P}_{2} \mathrm{O}_{7}$. From this table, it was found that when $\mathrm{Ca}\left(\mathrm{NO}_{3}\right)_{2}$ adding rate increased the crystal diameter decreases and crystallinity increases.

Table 4. The crystal diameter, crystallinity and average particle size of TCP powder synthesized at different $\mathrm{Ca}\left(\mathrm{NO}_{3}\right)_{2} \cdot 4 \mathrm{H}_{2} \mathrm{O}$ addition rates.

\begin{tabular}{|c|c|c|c|}
\hline $\begin{array}{c}\mathrm{Ca}\left(\mathrm{NO}_{3}\right)_{2} \text { addtion } \\
\text { Rate }(\mathbf{m l} / \mathbf{m i n})\end{array}$ & Crystal Diameter & Crystallinity & Average particle \\
\hline $\mathbf{3}$ & $(\mathrm{nm})$ & $\mathrm{X}_{\mathrm{C}}$ & Size $(\mathrm{nm})$ \\
\hline $\mathbf{3 0}$ & 56 & 72 & - \\
\hline $\mathbf{3 0 0}$ & 54 & 75 & $130-300$ \\
\hline
\end{tabular}

To confirm the XRD results, the morphology of TCP powder was further analyzed by TEM images. (Fig. 7) and Table 4 present the TEM images and TEM-based calculated average particle sizes. TCP particle had a spherical shape and highly agglomerated. It has been found that nanoparticles with spherical morphology are better than other irregular morphologies due to the good space fillings 
and the low percentage of voids in the final product ${ }^{26}$. However, when $\mathrm{Ca}\left(\mathrm{NO}_{3}\right)_{2}$ adding rate increased, particle size decreased. These results allowed concluding that the slow addition of precursors results in a regime favouring crystal growth and formation of larger particles.
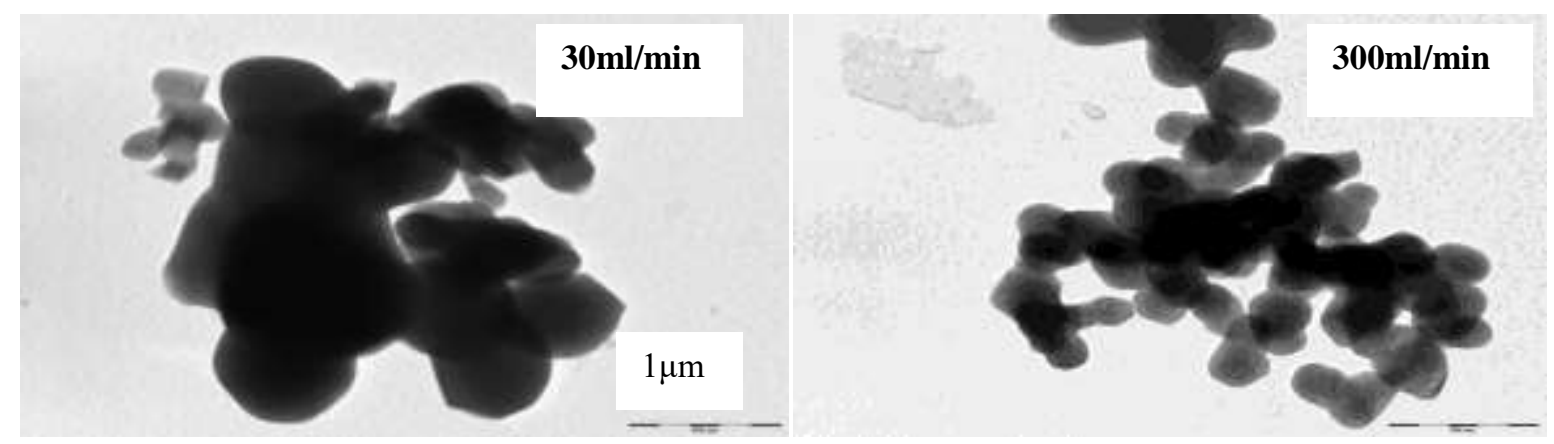

Figure 7. TEM images of TCP samples synthesized at a various addition rate

\section{Effect of $\mathrm{pH}$ of the reaction}

Two parameters govern which phase will form for a given calcium phosphate: the initial calcium to phosphate ratio of the reactants and the $\mathrm{pH}$ at which the reaction occurs. We synthesized TCP powder by dropping slowly $\mathrm{Ca}\left(\mathrm{NO}_{3}\right)_{2} \cdot 4 \mathrm{H}_{2}$ Osolution into $\left(\mathrm{NH}_{4}\right)_{2} \mathrm{HPO}_{4}$ solution at room temperature with various $\mathrm{pH} \mathrm{7,8}$ and 9 at an ageing time of $24 \mathrm{~h}$. The IR spectra of TCP powder synthesized at three $\mathrm{pH}$ values are shown in (Fig. 8). By comparing these IR results with data in Table 1, it was found that the obtained TCP had all the characteristic peaks of TCP. The very weak bands of the secondary phase, $\mathrm{Ca}_{2} \mathrm{P}_{2} \mathrm{O}_{7}$ at 727 and $1213 \mathrm{~cm}_{-1}$ appear in the sample synthesized with $\mathrm{pH}=7$. Also, the XRD results indicated the characteristic diffraction peaks of TCP, and no other phases of calcium phosphate were detected (Fig. 9) except for the spectrum of the sample synthesized with $\mathrm{pH}=7$ shows additional peak characteristic of the $\beta-\mathrm{Ca}_{2} \mathrm{P}_{2} \mathrm{O}_{7}$ phase.

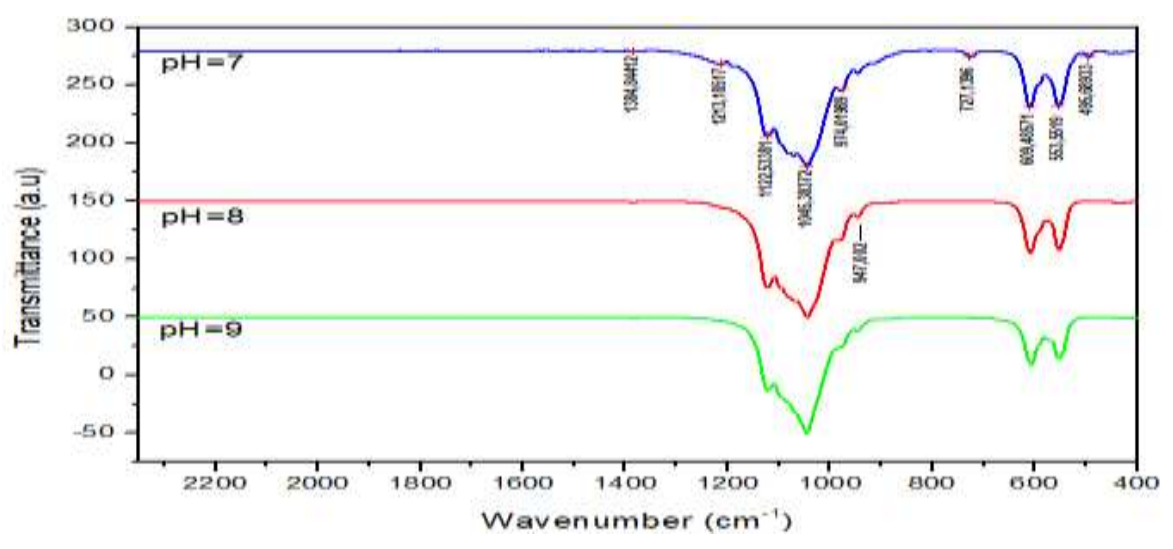

Figure 8. IR spectra of TCP powder synthesized at different $\mathrm{pH}$ values

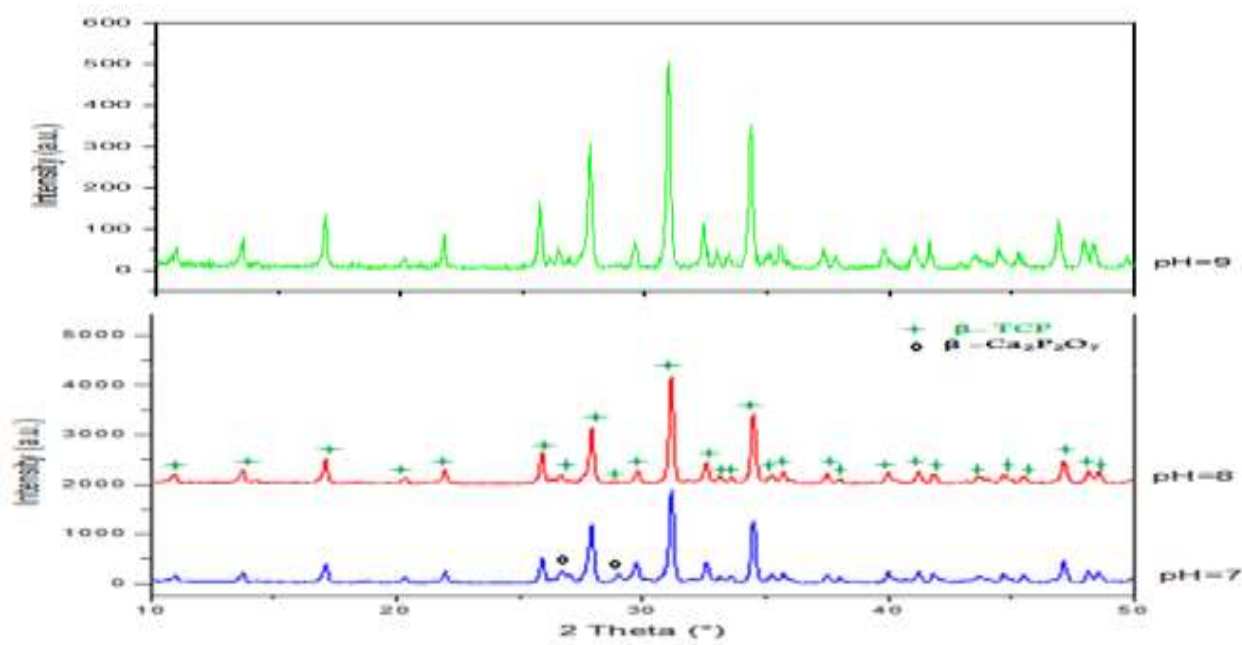

Figure 9. X-ray spectra of TCP powder synthesized at different $\mathrm{pH}$ values 
The data in Table 5 shows that the degree of crystallinity increase and become stable at $\mathrm{pH}=8$, XRD analyses also demonstrate a weak effect of $\mathrm{pH}$ (in the above-mentioned range) on the TCP crystal diameter, when the ph increased from 7 to 9 the crystallite size did not increase significantly, only from 40 to $43 \mathrm{~nm}$.

Table 5. The crystal diameter, crystallinity and average particle size of TCP powder synthesized at different $\mathrm{pH}$ values.

\begin{tabular}{|c|c|c|c|}
\hline $\mathbf{p H}$ values of & Crystal Diameter & Crystallinity & \multicolumn{2}{c|}{ Average particle } \\
\hline The reaction & $(\mathrm{nm})$ & $\mathrm{X}_{\mathrm{C}}$ & Size $(\mathrm{nm})$ \\
\hline $\mathbf{7}$ & 40 & 77 & $150-180$ \\
\hline $\mathbf{8}$ & 41 & 86 & $150-180$ \\
\hline $\mathbf{9}$ & 43 & 86 & $150-180$ \\
\hline
\end{tabular}

(Fig. 10) and Table 5 show the TEM images and average particle size of TCP calculated from the TEM images, respectively. The $\mathrm{pH}$ did not affect the morphology of TCP powder. As for the TEM results, it could be found that the TCP crystals had a spherical shape.

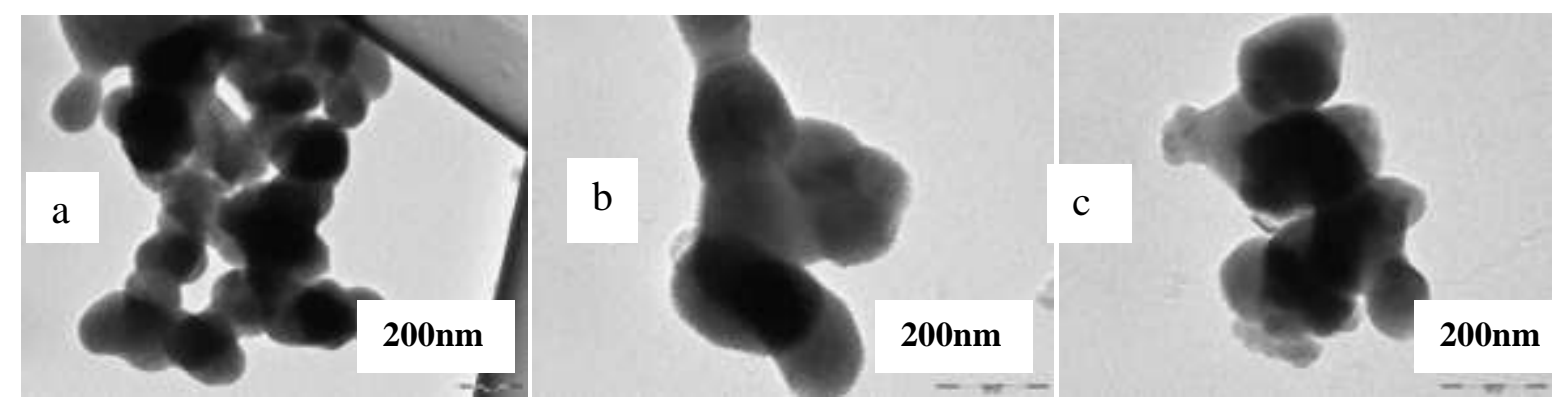

Figure 10. TEM images of TCP samples synthesized at $\mathrm{pH}=7$ (a), $\mathrm{pH}=8$ (b) and $\mathrm{pH}=9$ (c)

\section{Effect of ageing time}

The crystallinity and structural development of TCP is also affected by varying the ageing time of the precipitate. Longer ageing times ensure that reagents are fully reacted and precipitate out of the solution. The IR spectra of TCP samples prepared at $25^{\circ} \mathrm{C}, \mathrm{pH}$ $=9$ with various ageing times $2,24,48$ and 72 hours are shown in (Fig. 11). By comparing these IR results with data in Table 1, it was found that the spectrums are similar to that of $\beta-\mathrm{TCP}$, also, at 727, 1190 and $1213 \mathrm{~cm}^{-1}$, we can observe the presence of $\mathrm{P}_{2} \mathrm{O}_{7}{ }^{4-}$ group.
The XRD spectra of TCP powder prepared at different ageing times are represented in (Fig. 12). The characteristic diffraction peaks of TCP are indicated. The results showed that TCP synthesized at the different ageing time had the main crystalline phase present. The powder $72 \mathrm{~h}$ presents a slight shift in XRD peaks towards lower theta value; this may be due to the elongation in the crystal structure. Also, a minor amount of pyrophosphate was also found. However, the crystallite size and the degree of crystallinity increase with ageing time and become stable after $48 \mathrm{~h}$ for both (Table 6 )

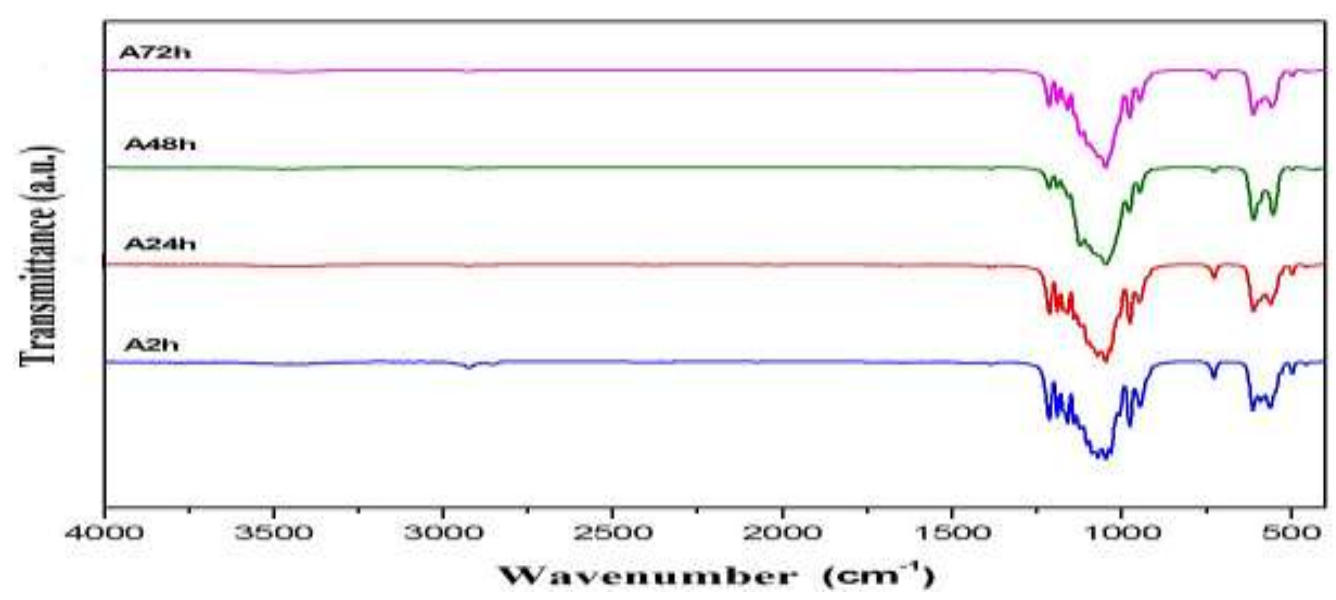

Figure 11. IR spectra of TCP powder synthesized at different ageing times 


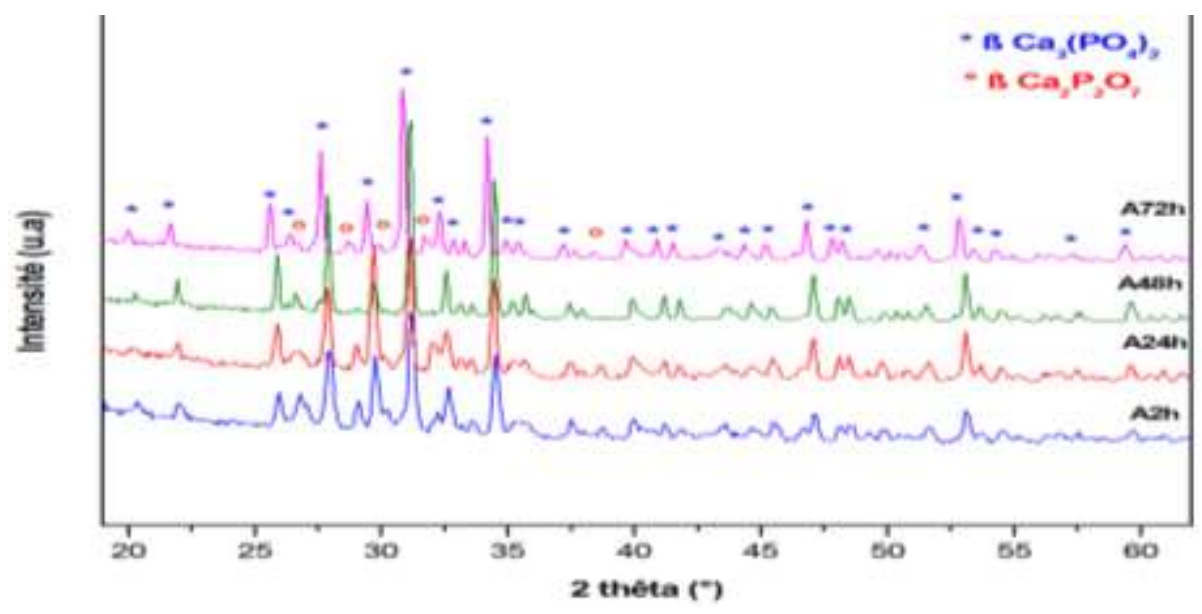

Figure 12. X-ray spectra of TCP prepared at different ageing times

The TEM images of TCP powder prepared at ageing times $2 \mathrm{~h}$ and $72 \mathrm{~h}$ are presented in (Fig. 13), At different ageing times, all obtained TCP had almost spherical and strongly agglomerated particles. The data in Table 6 shows that the particle size slightly increased with increasing ageing time.

Table 6. The crystal diameter, crystallinity and average particle size of TCP powder synthesized at the different ageing time.

\begin{tabular}{|c|c|c|c|}
\hline $\begin{array}{c}\text { Ageing time } \\
\text { (hours) }\end{array}$ & $\begin{array}{c}\text { Crystal Diameter } \\
(\mathrm{nm})\end{array}$ & $\mathrm{X}_{\mathrm{C}}$ & Crystallinity \\
\hline $\mathbf{2}$ & 32 & 83 & Size $(\mathrm{nm})$ \\
\hline $\mathbf{2 4}$ & 42 & 86 & - \\
\hline $\mathbf{4 8}$ & 42 & 95 & - \\
$\mathbf{7 2}$ & 42 & 94 & $\sim 400$ \\
\hline
\end{tabular}

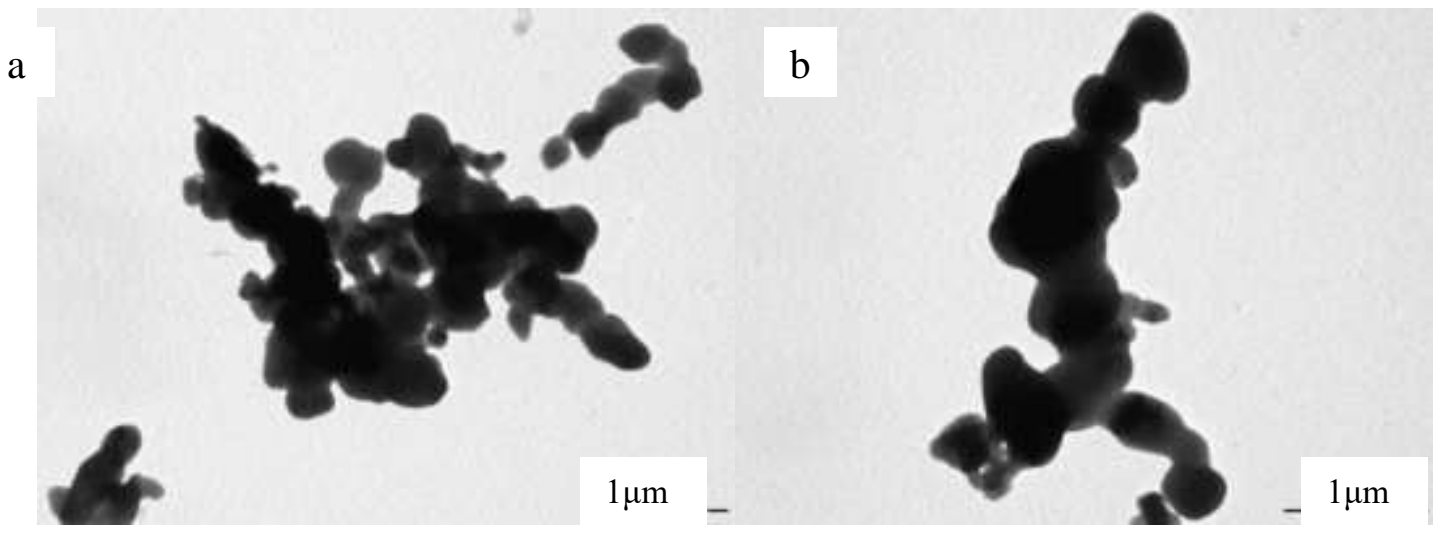

Figure 13. TEM images of TCP samples synthesized at different ageing times: (a) $2 \mathrm{~h}$, (b) $72 \mathrm{~h}$

\section{Conclusion}

Nano-sized $\beta$-Tricalcium phosphate powder was synthesized by the wet chemical method, by varying process parameter, followed by calcination, using calcium nitrate, diammonium phosphate solution as reactants, and ammonia as adjusting agent. The obtained results showed that the synthetic conditions were important in controlling the quality, shape and size of the TCP powder, but had significant effects on morphology. The calcined powders show the presence of two distinguishable crystalline phases $\beta$ Tricalcium phosphate and $\beta$-pyrophosphate or hydroxyapatite, spherical shape, crystallite size less than $60 \mathrm{~nm}$ and a high degree of crystallinity. All the results obtained allow determining the optimal conditions for synthesizing pure nanosized $\beta$-TCP with a high degree of crystallinity and a crystalline size of less than $50 \mathrm{~nm}$. Indeed, a synthesis temperature of $50{ }^{\circ} \mathrm{C}$, a dropping rate of $300 \mathrm{ml} . \mathrm{min}^{-1}$, ageing time of $48 \mathrm{~h}$ and a $\mathrm{pH}$ of about 9 are considered as the best synthesis conditions.

\section{References}

1- A. Tevlek, P. Hosseinian, C. Ogutcu, M. Turk, H.M. Aydin, Bi-layered constructs of poly (glycerol-sebacate) tricalcium phosphate for bonesoft tissue interface applications, Mater. Sci. Eng. C, 2017, 72, 316-324.

2- S. Hoover, S. Tarafder, A. Bandyopadhyay,

S. Bose, Silver doped resorbable tricalcium phosphate scaffolds for bone graft applications, 
Mater. Sci. Eng. C, 2017, 79, 763-769.

3- J. Park, S.J. Lee, H.H. Jo, J.H. Lee, W.D. Kim, J.Y. Lee, S.A. Park, Fabrication and characterization of 3D-printed bone-like tricalcium phosphate/polycaprolactone scaffolds for dental tissue engineering, J. Ind. Eng. Chem., 2017, 46, 175-181.

4- B.T. Smith, M. Santoro, E.C. Grosfeld, S.R. Shah, J.J.J.P. van den Beucken, J.A. Jansen, A.G. Mikos, Incorporation of fast dissolving glucose porogens into an injectable calcium phosphate cement for bone tissue engineering, Acta Biomater., 2017, 50, 68-77.

5- M. Fathi, A. El Yacoubi, A. Massit, B. Chafik El Idrissi, Wet chemical method for preparing high purity $\beta$ and $\alpha$ - tricalcium phosphate crystalline powders, IJSER, vol6, Iss6, 2015, 139-143.

6. Cen Y, Zhang TH, Gan CH, Yu G Wear studies of hydroxyapatite composite coating reinforced by carbon nanotubes. Carbon, 2007, 45, 998-1004. 7. Klein CPAT, Driessen AA, Groot K, Hoof A Biodegradation behavior of various calcium phosphate materials in bone tissue. J Biomed Mater Res, 1983, 17, 769-784.

8- L. Sha, Y. Liu, Q. Zhang, M. Hu, and Y. Jiang, Microwave-assisted co-precipitation synthesis of high purity $\beta$-tricalcium phosphate crystalline powders, Materials Chemistry and Physics, vol. 129, no. 3, 2011, 1138-1141.

9- Y. Pan, J.L. Huang, C.Y. Shao, Preparation of $\beta$-TCP with high thermal stability by solid reaction route, J. Mater.Sci., 2003, 38, 1049-1056.

10- B. Chafik El Idrissi, K. Yamni, A. Yacoubi, A. Massit, A novel method to synthesize nanocrystalline hydroxyapatite: Characterization with x-ray diffraction and infrared spectroscopy,IOSR Journal of Applied ChemistryVol7, Issue 5 Ver. III, 2014, 107-112.

11- S.C. Liou, S.Y. Chen, Transformation mechanism of different chemically precipitated apatitic precursors into $\beta$-tricalcium phosphate upon calcination, Biomaterials, 2002, 23, 4541-4547.

12- A. Cuneyt Tas, F. Korkusuz, M. Timucin, N. Akkas, An Investigation of the Chemical Synthesis and High-Temperature Sintering Behaviour of Calcium Hydroxyapatite (HA) and Tricalcium Phosphate (TCP) Bioceramics, J.

Mater.Sci.Mater.Med., 1997, 8, 91-96.

13- A. Farzadi, M. Solati-Hashjin, F. Bakhshi, A. Aminian, Synthesis and characterization of hydroxyapatite/b-tricalcium phosphate nanocomposites using microwave irradiation, Ceramics International, 2011, 37, 65-71.

14- Li Shaa, YuyanLiub, Qing Zhanga, Min Hub, Yinshan Jiang, Microwave-assisted coprecipitation synthesis of high purity tricalcium phosphate crystalline powders, Materials Chem and Phys , 2011, 129, 1138-1141.
15- M.B. Thürmer, C.E. Diehl, L.A.L. dos Santos, Calcium phosphate cements based on alphatricalcium phosphate obtained by wet method: synthesis and milling effects, Ceram. Int., 2016 , 42, 18094-18099.

16- C. Ruiz-Aguilar, et al., Characterization of tricalcium phosphate powders synthesized by sol-gel and mechanosynthesis, Bol. Soc. Esp. Cerám. Vidr. 2018, 213-220.

17- A. Destainville, E. Champion, D. BernacheAssollant, E. Laborde, Synthesis, characterization and thermal behaviour of apatitic tricalcium phosphate, Materials Chemistry and Physics, 2003, 80, 269-277.

18- S. Raynaud, E. Champion, D. Bernache-Assollant, J.-P. Laval, Determination of calcium/phosphate atomic ratio of calcium phosphate apatites using $\mathrm{X}$-ray diffractometry, J.Am. Ceram. Soc., 2001, 84, 359-366.

19- M. Santos, M. Oliveira, L. Souza, H. Mansur, W. Vasconcelos, Synthesis Control and Characterization of Hydroxyapatite Prepared by Wet Precipitation Process, Materials Research, 2004, 7, 625-630.

20- R.G. Carrodeguas, A.H. De Aza, I. GarciaPaez, S. De Aza, P. Pena, Revisiting the PhaseEquilibrium Diagram of the $\mathrm{Ca}_{3}\left(\mathrm{PO}_{4}\right)_{2}-$ $\mathrm{CaMg}\left(\mathrm{SiO}_{3}\right)_{2}$ System, J. Am. Ceram. Soc., 2010, 93, 561-569.

21- K.P.Sanosh, Min-Cheol Chu, A.Balakrishnan T.N.Kim, Seong-JaiCho, Sol-gel synthesis of pure nano-sized $\beta$-tricalcium phosphate crystalline powders, Current Applied Physics, 2010, 10, 68-71.

22- B. Nasiri-Tabrizi, A. Fahami, Production of poorly crystalline tricalcium phosphate nanopowders using different mechanochemical reactions, J. Ind. Eng. Chem. 2014, 1236-1242.

23- T. Nakano, A. Tokumura, Y. Umakoshi, Variation in crystallinity of hydroxyapatite and the related calcium phosphates by mechanical grinding and subsequent heat treatment, Metallurgical and Materials Transactions A, 2002, 33, 521-528.

24- K.P. Sanosh, M.C. Chu, A. Balakrishnan, Y.J. Lee, T.N. Kim, S.J. Cho, Synthesis of nanohydroxyapatite powder that simulates teeth particle morphology and composition, Current Applied Physics, 2009, 9, 1459-1462.

25- A. Massit, A. El Yacoubi, A. Rezzouk, B. Chafik El Idrissi, Preparation of Tricalcium phosphate: effect of precursor addition rate on the microstructural properties, IJASTR, Issue 5 vol 4 , 2015, 617-625.

26- B. Nasiri-Tabrizi, A. Fahami, R.EbrahimiKahrizsangi, Effect of milling parameters on the formation of nanocrystalline hydroxyapatite using different raw materials in, Ceramics International, 2013, 39, 5751-5763. 